Euskal ikerketen aldizkaria | Revue d'études basques |

Revista de estudios vascos | Basque studies review

$13 \mid 2009$

Numéro XIII

\title{
Zenbatzaileak komunztatzen ez direnean : Hiru sistema
}

Urtzi Etxeberria et Ricardo Etxepare

\section{OpenEdition}

Journals

Édition électronique

URL : http://journals.openedition.org/lapurdum/2032

DOI : 10.4000/lapurdum.2032

ISSN : 1965-0655

\section{Éditeur}

IKER

Édition imprimée

Date de publication : 1 février 2009

Pagination : 127-144

ISBN : 978-2-86781-409-X

ISSN : $1273-3830$

Référence électronique

Urtzi Etxeberria eta Ricardo Etxepare, «Zenbatzaileak komunztatzen ez direnean : Hiru sistema », Lapurdum [Linean], 13 | 2009, Sarean emana----an 15 avril 2013, kontsultatu 30 avril 2019. URL : http:// journals.openedition.org/lapurdum/2032 ; DOI : 10.4000/lapurdum.2032 


\title{
Zenbatzaileak komunztatzen ez direnean: Hiru sistema
}

\author{
Urtzi ETXEBERRIA eta Ricardo ETXEPARE ${ }^{1}$ \\ CNRS-IKER
}

\begin{abstract}
:
Basque weak quantifiers optionally agree with the inflected verb in number. This papers' main aim is to study the dialectal variation shown by this phenomenon. The study will show that it is necessary to differentiate at least three systems: the western-central system, the transition system, and the oriental system. The differences are twofold: (i) some concern the syntactic contexts in which the optional agreement is allowed. The western-central system allows it with every argument position; the transition system does not allow it with ergative case arguments, and the oriental system allows it only with absolutive case arguments; (ii) the rest concern the set of quantifiers that permit optional agreement: in the oriental system, weak cardinal quantifiers need not agree with the inflected verb; in the rest of the systems, agreement is obligatory in these cases. This difference appears to be related to the ability to use bare nouns within the oriental system: bare nouns show the same syntactic distribution as non-agreeing weak cardinal quantifiers.
\end{abstract}

\section{Laburpena:}

Euskarazko zenbatzaile ahulek pluraleko komunztadurarik gabe agertzeko aukera dute. Artikulu honek fenomeno horren baitan gertatzen den bariazio dialektala aztertu nahi du. Azterketa honek gutxienez hiru sistema bereizi behar ditugula erakusten du: mendebalde-erdialdekoa deituko duguna, trantsiziokoa (Lapurdiko hiztun zenbaitetan aurkitu duguna) eta ekialdekoa deitu duguna, Coyos-en (1999) Arbailetako (Zuberoa) hizkeraren azterketan oinarritua. Diferentziak bi mailatakoak direla erakutsiko dugu: (i) komunztadura eza zein kontestu sintaktikotan gertatzen den. Erdialdeko-mendebaldeko hizkerek argumentu guzietan agertzen dute; trantsiziokoak ez du ergatiboarekin agertzen, eta ekialdeko hizkerek absolutiboekin bakarrik onartzen du; (ii) fenomenoa erakusten duten zenbatzaileen multzoa bera: zubereraz, zenbatzaile kardinalek ez dute

1. Ikerketa hau ondorengo proiektuen laguntzari esker burutu ahal izan da: Euskal Herriko Unibertsitateko 9/UPV00114.130-16009/2004 proiektua; Euskal Gobernuko IT-210-07, Ikerketa Sareak/Humanitate Arloa 2007: Licensing conditions at the interfaces proiektuak; CNRS-ko Fèderation Typologie et Universaux Linguistiques-eko FR2559 proiektua; ANR-ko TSABL (ANR-07-CORP-033) proiektua; MCI-ko FFI2008-00240 proiektua, eta Eusko Jaurlaritzako GIC07/144-IT-210-07.

Kontakturako e-postak: u.etxeberria@iker.cnrs.fr / retxepare@iker.cnrs.fr. Eskerrak eman nahi dizkiegu Bernat Oihartzabali eta Celine Mounhole-ri izan ditugun eztabaidengatik eta beren intuizioak gurekin partekatzeagatik. 
zertan pluraleko komunztadura egin; beste sistemetan komunztadura ezinbestekoa da. Diferentzia hau iduriz ekialdeko hizkerek (gainontzeko hizkerek ez bezala) izen biluziak erabiltzeko duten gaitasunarekin lotzen da: izen biluziek zenbatzaile kardinal komunztaduragabeen distribuzio ia berdina erakusten dute.

Gako hitzak: zenbatzaile ahulak, izen zenbakaitzak, numero komunztadura, distribuzioa, izen biluziak

Keywords: weak quantifiers, mass terms, number agreement, distribution, bare nouns

\section{Fenomenoa}

Pluraltasuna denotatzen duten gainerako izenezko egiturek ez bezala (1), euskararen zenbatzaile ahul 'lauso' gehienek ${ }^{2}$ aditzarekin pluralean komunztatzeko aukera izateaz gain badute aditzarekin inolako komunztadurarik ez egiteko aukera (2a-d), beren interpretazio plurala gora-behera (Rotaetxe 1979; Txillardegi 1977, 1978; EGLU 1985; Etxepare, 2000).

(1) Ikasleak ikusi ditut/*dut

(2) a. Bezero asko etortzen da/dira halako egunetan

b. Hainbat ikaslek arazoak izango ditu/dituzte

c. Zenbait artistak ez daki/dakite zer egin bere(n) diruarekin ${ }^{3}$

d. Bezero gehiegik eskatu du/dute arrain zopa

e. Ikasle gutxi ikusi dut/ditut gaur

Alternantzia hau beste zenbatzaile ahul batzuetara ere zabaltzen da: ugari, pila bat, num-inguru, NP-ren bat edo beste, num baino gehiago, gehiegi, gutxiegi, e.a. Lan honetan halere, asko (erdialde-mendebaldeko euskaretan) eta anitz (ekialdeko euskaretan) zenbatzaileetan ipiniko dugu arreta. Gainerakoen portaera hauenarekin parekatzen dela asumituko dugu, nahiz eta badakigun hau ez dela beti horrela. ${ }^{4}$

Alternantzia honi begiratuta sortzen den berehalako galdera bat da zehazki zer alternantzia mota den: numero pluralaren eta singularraren arteko alternantzia bat al da? Ala singularreko komunztadura besterik ezean azaleratzen den forma da, beste edozein numero markaren ausentzian aukeratzen dena? Ez da erraza galdera hau erantzuten forma komunztatuei soilik begiratuez gero. Halere, beste testuinguru sintaktiko batzutara mugitzen baldin bagara, ondorioztatu dezakeguna zera da: 3. pertsona singularreko komunztadura, euskarako zenbatzaile ahul 'lauso'en testuinguruan, besterik ezeango forma dela, numero ezaugarriekin inolako korrespondentziarik ez duena. Aski argigarriak dira hartara numero komunztadura beharrezkoa duten bigarren mailako predikazioak (ikus Artiagoitia, 1994).

(3) Ikasleak nekatu(*ak) antzeman ditut

2. Ikus Etxeberria $(2005,2007)$ euskal zenbatzaile sendoen eta ahulen arteko banaketa zein den eta banaketa hau zein propietateei zor zaien ikusteko. 'Lauso' terminoak kardinalitaterik zehazten ez duten zenbatzaile ahulak biltzen ditu.

3. Zenbait eta hainbat-ek ere alternantzia hau erakusten dute. Halere, zenbatzaile hauek beste propietate batzuk ere erakusten dituzte eta ez ditugu lan honetan landuko; ikus Etxeberria \& Etxepare (2008).

4. Ikus Etxeberria \& Etxepare (2008, prestakuntzan). Mendebalde, erdialde eta ekialde terminoak Zuazo (1998)ren banaketa dialektalarekin lotu behar dira. 
Goiko adibidean, Perpaus Txiki bat daukagu, nekatuak predikatua duena, zeinak nahi eta nahi ez numero komunztadura erakutsi behar duen ikasleak subjektuarekin. Orain, jar dezagun arreta (4) adibideko kontrastean:

(4) a. Ikasle asko nekatuak antzeman ditugu

b. * Ikasle asko nekatua antzeman dugu

Aditzarekin pluraleko komunztadura erakusten duen zenbatzaile lauso batek bigarren mailako predikatu bat (plurako $-\boldsymbol{k}$ atzizkiarekin, (4a)) baimentzen duen bitartean, komunztadurarik erakusten ez duen zenbatzaile lauso batek ezin dezake singularreko komunztaduradun bigarren mailako predikaturik baimendu. Hemendik ondoriozta dezakeguna da pluraleko komunztadurarik erakusten ez duten zenbatzaileek ez dezaketela singularreko komunztadurarik erakutsi, eta ondorioz, aztertzen ari garen zenbatzaile formek ez dutela inolako numero ezaugarririk, ez pluralekorik ez eta singularrekorik ere. Arazoa numero komunztaduran dagoela, eta ez komunztaduragabeek izan lezaketeken bigarren mailako predikatuak baimentzeko gaitasunean, numerorik ez duten bigarren mailako predikatuek erakusten dute. Hauxe da esate baterako euskarako -rik atzizki partitiboarekin lortzen duguna, zeinak ez baitu numero komunztadurarik erakusten. Atzizki partitiboak bigarren mailako predikatu batekin agertzeko zenbait baldintza semantiko eman behar dira (ikus Etxepare, 2003; Zabala, 1993, 2003). Atzizki partitiboak [D+numeroa] atzizkia ordezkatzen duenean, zenbatzaile lausoak bigarren mailako predikazioa baimentzen du (5a). Gauza bera gertatzen da numero komunztadurarik ager ez dezakeen -ta arzizkiarekin (5b).

(5) a. Ikasle asko nekaturik dago

b. Ikasle asko nekatuta dago

Lan hau jarraian zehazten den bezala dago antolatua: 2. atalean zenbatzaileek erakusten duten komunztadura alternantziak jaso duen analisia aurkeztuko dugu; 3. atalean ikuspegi honen kontrako argudioak aurkezten ditugu; 4-7 ataletan, zenbatzaile komunztaduragabeek erakusten dituzten propietateetan oinarrituz, 3 sistema desberdintzen ditugu: Mendebalde-Erdialdekoa, Trantsiziokoa (Lapurdikoa) eta Ekialdekoa (Zuberoakoa). 8. atalean zubererako artikuluaren erabilera ezak eta hizkuntza erromantzeetako artikuluaren erabilera ezak dituzten antzekotasunak azaltzen ditugu. 9. atalean ondorio batzu agertzen ditugu.

\section{Orain arteko ikuspegia: Komunztaduragabeak masa izenak dira.}

Euskaltzaindiak (1985:223-224) zenbatzaile ahul lausoen komunztadura falta masa izenen numero markatze ezarekin parekatzen du.

(6) a. Haragi asko jaten du

b. Haragi asko jaten ditu

Numero komunztaduraren presentziak (6b)ko masa izaeradun haragi izenaren interpretazio zenbagarria bultzatzen du, haragi mota indibidualizatuen multzo bat edo. Euskaltzaindiaren gramatikak izen zenbagarriekin numero komunztadurarik ez erabiltzeak kontrako efektua bultzatzen duela ematen du aditzera. Ondorengo esaldiak ematen ditu gramatikak: 
(7) a. Liburu asko erosi dut

b. Liburu asko erosi ditut

Euskaltzaindiaren (1985:223) esanetan, (6a-7a) eta (6b-7b)k ez dute interpretazio bera: “... lehenbiziko adibidean liburu masa hartzen dugu gogoan. Bigarrenean, berriz, liburu bat, eta beste bat e.a.". Beraz, komunztaduraren desagertzea zenbagarriak diren izenezko adierazpideen baitan zenbakaitzak direnengan komunztaduraren agertzeak eragiten duen tipo-aldaketaren kontrakoa eragingo luke: numero komunztadurak masak zenbagarri bihurtzen ditu; numero komunztaduraren ezabatzeak izen zenbagarriak zenbakaitz bihurtuko lituzke.

\section{Komunztaduragabeko zenbatzaile sintagmen ustezko masa izaera}

Badira hainbat arrazoi pentsatzeko komunztaduragabeko zenbatzaileek ez dutela masen edo izen zenbakaitzen gisa jokatzen. Intuitiboki, komunztadurarik agertzen ez duten zenbatzaile sintagmek ez dute masa izaera duten bestelako izenek duten esanahia. Pelletier-ek (1975) asmaturiko honako gogo-esperimentuak masa izen ohikoenen denotazioa agerian utziko luke. Bere gogo-esperimentuak bi tresna proposatzen ditu: Zirtzikagailu Unibertsala (Universal Grinder) eta Objektu-egile Unibertsala (Universal Objectifier). Imajina dezagun tresna bat edozer gauza txikitu dezakeena. Orain hartu edozein izen zenbagarrik denotatzen duen zer bat eta makina horretatik pasarazi. Izen berbera erabiltzen badugu makinaren beste aldetik pasatzen dena izendatzeko, izen horrek orain masa bat izendatzen du. Har dezagun sagar izena gure izen zenbagarri bezala, sagar bat Zirtzikagailu Unibertsaletik pasatzen baduzu jasotzen duzuna sagar xehatua da, hau da, masa denotatuko lukeen sagarra, (10) adibidean ulertzen duguna hain zuzen ere.

(8) Entsaladak sagar pixka bat dauka

Kontrako funtzioa izango luke objektu-egile unibertsala deituak. Bistan da gure komunztaduragabeko formek ez dutela horrelako zerbait izendatzen. (9) bezalako zerbaitek, bere adiera arruntenean, ikasleak osorik ditu:

(9) Ikasle asko ikusi dut gaurko batzarrean

Egia da Pelletier-en esperimentuak ez duela masa-izenen alor osoa besarkatzen. Ingelesezko furniture (edo euskarazko baxera), masa-izena da, baina baxera osoa eta baxera txikitua ez dira gauza bera. Pelletier-en esperimentua zenbagarri nahiz zenbakaitz izan daitezkeen izenei dagokiela esan genezake. Hor ere, ez dator bat komunztadura kentzerakoan zenbatzaile sintagmek erakusten duten interpretazioarekin:

(10) Plater honetan sagar asko ikusten dut Zenbakaitz: 'sagar xehetu/puska'

Zenbagarri: 'sagar ale'

Bi irakurketak itxuraz antzekoa den honako gaztelaniazko fenomenoarekin konpara ditzakegu:

(11) a. Hoy hemos visto mucho Indurain

$\rightarrow$ Indurain ezaugarritzen duten bertuteen agerpen aski konplitu bat 
[hitz abstraktuak=masak]

b. Hoy hemos visto a mucho Indurain

$\rightarrow$ ironiaz tour-aren garaian errepideak betetzen dituzten txirrindulari amateurrengatik esana

Lehen kasua (11a) Indurainek Galibierreko tontorra garaile igaro zuen egun gogoangarri haietako batean esan litekeen zerbait da: bere onenean agertu da txirrindularia, eta izen abstraktu gisa hartuta (Indurainen txirrindulari ahalmenak azaltzen dituen objektu abstraktu baten gisa) ${ }^{5}$ haren gaineko zenbaketa bat egiten dugu, bertute horien agerpen aski konplitua izan dela esanez. Bigarren kasuak, (11b)-k, ez digu hori esateko balio. Esaldia egoki egingo lukeen kontestu bat hauxe izango litzateke: tourraren garaia da, eta ohi bezala, errepideak mukuru daude txirrindulariak berdindu nahi dituzten zaleez. Haiei ironiaz erreferentzia eginez esan genezake (11b) bezalako zerbait. Bestela esanda, (11b)-k egitura atomiko garbia dauka, eta bizikletan ari diren gizabanakoez ari da, ezinbestean. Kontua da euskarazko komunztaduragabeko formak nahitaez (11b)-ren tankerakoak direla. (12) perpausak ez dezake, gure belarrietan behintzat, (11a)-ren adiera bera izan; bai ordea (11b)-rena:

\section{(12) Gaur Indurain asko ikusi dugu [(11b)-ren kidea bakarrik]}

Euskarazko zenbatzaile sintagma komunztaduragabeek beraz ez dute beren oinarri atomikoa galtzen. Masa izenak eta komunztaduragabeko formak bereizten dituzten beste ezaugarri batzuk ondorio berberera garamatzate. Lonning-ek (1987) erakutsi bezala, masa terminoak ezin daitezke predikazio erlazioan agertu "homogenotasunaren" propietatea erakusten ez duten predikatuekin ${ }^{6}$. Zenbagarriak bai:

(13) a. * Ur askok 300 kilo baino gehiago pisatzen du

b. Zaldi askok 300 kilo baino gehiago pisatzen du

Aldiberean, masa izenez osaturiko zenbatzaile sintagmak predikatu gisa ager daitezke, ez ordea izen zenbagarriz osaturikoak:

(14) a. Eraztun hori urre asko da

b. Zaku hori harri asko da

d. * Multzo/talde hori ikasle asko da

Azkenik, komunztadura eza ez da asko-ren afera hutsa (ikus (1)). Beste zenbatzaile batzuk ere erakusten dute. Eta badira horien artean masa izenekin ezin ager daitezkeenak (izenaren masa denotazioa aldatu gabe): ${ }^{7}$

5. Ikus Koslicki (1999) izen abstraktuen eta masen arteko loturaz.

6. Homogenoak diren predikatuak kumulatiboak eta banagarriak (divisive) dira (ikus Link 1983).

7. (15)-ko perpausak gramatikalak dira baldin eta ardo klaseak (Errioxakoa, e.a.) edo ardo kantitateak (edalontzi bat eta beste bat) zenbatzen baditugu, baina jakina, hori ez da masa irakurketa. Ikus 2 oinoharra. 
(15) a. * Zenbait ardo edan dugu

(masa interpretazioan)

b. * Hainbat ardo edan dugu

(masa interpretazioan)

Orainarte, zenbatzaile ahul lauso komunztaduragabeak eta masa izenak zertan bereizten diren erakutsi dugu. Hemendik aurrerako ataletan, zenbatzaile komunztaduragabeek erakusten duten bariazioan zentratuko gara bereziki, bariazio horren deskribapen ahalik eta zehatzena emanez. Euskararen barnean gutxienez hiru sistema bereizi behar ditugula erakutsiko dugu: Mendebalde-Erdialdekoa, Trantsiziokoa deituko dugun bat (Lapurdin aurkitua) eta Ekialdekoa (Zuberoakoa).

\section{Komunztadura gabeen erabilera: Mendebalde-Erdialdekoa}

\subsection{Komunztatzen ez diren zenbatzaileen distribuzio sintaktikoa}

Mendebalde-Erdialdeko sistema honetan zenbatzaile ahul komunztaduragabeak edozein posizio sintaktikotan eta edozein kasu markarekin ager daitezke: subjektu (S) posizioan, kasu ergatiboarekin nahiz kasu absolutiboarekin (16a); zehar objektuaren (ZO) posizioan, kasu datiboarekin (16b); eta objektu zuzenaren (OZ) posizioan, kasu absolutiboarekin (16c).

(16) a. Subjektua:

$$
\text { Kasu erg.: } \quad \text { Azkenean gazte asko-k altxatu behar izan zuen harria }
$$

Kasu abs: $\quad$ Ikasle asko etorri da festara

b. Zehar objektua:

Kasu dat: $\quad$ Ugazabak langile asko-ri eskatu dio laguntza

c. Objektu zuzena:

Kasu abs.: $\quad$ Mirenek liburu asko ikusi du liburutegian

\subsection{Komunztaduragabeen izaera distributiboa}

Zenbatzaile ahul komunztaduragabeen propietate bereizgarrietako bat beren izaera distributiboa da (Etxepare, 2000). Propietate honek noski, murriztapen batzuk ezartzen ditu zenbatzaile ahul komunztaduragabeak konbina daitezkeen predikatuekiko.

4.2.1. Irakurketa kolektibo eta distributiboak

Har dezagun (17) eta (18) adibideen arteko kontrastea:

(17) Azkenean gazte askok altxatu behar izan zuten harria

$\checkmark$ kolektiboa $\quad \checkmark$ distributiboa

(18) Azkenean gazte askok altxatu behar izan zuen harria

$$
\text { * kolektiboa } \quad \checkmark \text { distributiboa }
$$

(17)-n zenbatzaile ahula aditzarekin komunztatzen da, eta esaldiak bi irakurketa izan ditzake: bata distributiboa, non taldeko gazteek harria bakarka altxatu zuten, eta bestea kolektiboa, non gazteen multzoak elkarrekin altxatzen duen harria. (17)-k tarteko irakurketak ere baimentzen ditu. Irakurketa distributibo hauek ohikoak dira entitate zenbagarri pluralez ari garenean (ikus Krifka, 1992). (17)-ko adibideak ez bezala, (18)-k irakurketa distributibo hertsia baizik ez du onartzen, zeinetan gazteek harria banan-banan altxatzen duten eta ondorioz gazteak adina harri altxatze egongo diren. 


\subsubsection{Predikatu klaseak}

Zenbatzaile komunztaduragabeak distributiboak badira, hemendik jarraitzen dena da banakako interpretazioa onartzen ez duten predikatuekin ez direla ondo joango. Komunztaduradunek berriz, ez dute inolako arazorik izango predikatu klase honekin konbinatzeko. Predikzioa, ondorengo adibideek garbi erakusten duten bezala, betetzen da.

(19) a. Ikasle ohi askok festa horretan topo egin zuten

b. * Ikasle ohi askok festa horretan topo egin zuen

(20) a. Lantegian, langile asko batzartu dira

b. ?* Lantegian, langile asko batzartu da

(21) a. Mozio hori, zinegotzi askok adostu zuten

b. * Mozio hori, zinegotzi askok adostu zuen

(22) a. Jonek liburu asko ordenatu ditu

b. ?? Jonek liburu asko ordenatu du

Batzartzeak edo adostasun batetara iristeak indibiduo baten baino gehiagoren partehartzea eskatzen duten erlazioak adierazten dituzte eta irakurketa kolektiboak bultzatzen dituzte. Modu honetako erlazioak adierazten dituzten predikatuak ez dira bateragarri zenbatzaile komunztaduragabeekin.

\subsubsection{Elkarkariak}

Zenbatzaile komunztaduragabeez hornituriko sintagmek beti interpretazio plurala duten arren, elkarkariak ezin txerta daitezke hauek agertzen diren testuinguruetan.

(23) a. Ikasle askok elkarren/bata bestearen antz handia dute

b. * Ikasle askok elkarren/bata bestearen antz handia du

(24) a. Irakasle askok elkar/bata bestea iraintzen dute

b. * Irakasle askok elkar/bata bestea iraintzen du

Heim, Lasnik eta May (1991): elkarkariek badute (elkarkari izate hutsagatik, hots beren egitura logikoan) distributiboa den atal bat, zenbait hizkuntzatan agerikoa dena (each other). Zenbatzaile distributiboek plurala den multzo baten baitan operatzen dute. Distribuzio operadorearen zeregina multzo plurala banakako aletan banatzea da eta ale bakoitzari buruz predikazio bat ahalbidetzea. Honek esan nahi du ezin dela bi aldiz distribuzioa egin. Lehenengo banaketak multzo plurala banako aletan desegin du dagoeneko, eta banako ale horietan ezin da berriro distribuziorik egin. Komunztaduragabeko asko distributiboa da berez. Heim, Lasnik eta May-k arrazoia badute orduan (b) kasuetan bi distribuzio operadoreren aurrean gaude, eta horietako batek ez du banaketarik egiten ahal. Problema beraz semantikoa da. Ez da gauza bera gertatzen pluraleko formekin: hauek ez dute nahitaez interpretazio distributiborik. Hortaz operadore distributibo bakarra elkarkariak berak ekarritakoa da.

Konpara dezagun (24b) (25)ekin, non euskarako berezko zenbatzaile distributiboa den bakoitz erabiltzen dugun. ${ }^{8}$ Bakoitz, distributibotasunari dagokionean, komunztaduragabeko zenbatzaile

8. Ikus Etxeberria $(2005,2008)$ bakoitz zenbatzaile distributiboaren propietateen deskribapen bat ikusteko. 
ahulak bezala portatzen da:

(25) * Ikasle bakoitzak elkar ikusi du

\section{3 . Predikatu thetiko eta kategorikoak}

Euskaraz, espainolez bezala (ikus Lujan, 1981; Schmitt, 1992; Fernández Leborans, 1999), kopula lokatiboa eta kopula ezaugarriztatzailea desberdintzen ditugu (Etxepare, 2003). Intuitiboki, egon kopula lokatiboak une jakin bateko ezaugarria ezartzen dio predikazioaren subjektuari (26b), izan kopulak berriz berezko eta betiereko propietate bat lotzen dio (26a).

(26) a. Jon oso barregarria da

b. Jon oso barregarri dago (mozorro horrekin)

Zenbatzaile komunztaduragabeak ezin ager daitezke izan kopuladun predikatuen subjektu bezala:

(27) a. Ikasle asko altuak/azkarrak dira

b. * Ikasle asko altua/argia da

Aldiz, ez dute inolako arazorik egon kopuladun predikatuen subjektu bezala agertzeko:

(28) a. Ikasle asko gaiso(rik) daude egunotan

b. Ikasle asko gaiso(rik) dago egunotan

Bi kasu hauen arteko desberdintasuna Egoera-Mailako (EM) eta Izaera-Mailako (IM) predikazioen arteko desberdintasuna bezala defini daiteke (Carlson, 1979; Kratzer, 1989, 1995). Beraz, badirudi, zenbatzaile komunztaduragabeak EM predikatuekin bakarrik ager daitezkeela.

Bereizketa honen inguruan hausnarketan hasi baino lehen, beharrezkoa deritzogu bereizketa hau azalduko lukeen arrazoi hutsal bat baztertzea. Artiagoitia (1994) ohartzen da euskarazko IM predikatuak artikuluaz lagundurik agertu behar dutela (ikus Eguren 2006 azapen posible batetarako). Artikuluak nahitaez numero ezaugarriak dakartza berarekin. Zenbatzaile komunztaduragabe lausoek inolako numero markarik ez dutenez, (27b)ren ezgramatikaltasunaren arrazoia honakoa izan liteke: zenbatzaile komunztaduragabeak ez du numero tasunik eta horrenbestez ez daiteke numero tasunak dituen predikatuarekin batu. Arazoa ez dago halere numero markaren presentziara mugatua. Hartu esate baterako euskarazko -ago atzizki konparatiboa. Atzizki hau erroari lotzen zaio zuzenean:

$$
\left[_{\text {Adjektiboa }} \text { handi }\right]+\text { ago } \rightarrow \text { handiago }
$$

Aldaera batzutan, atzizki konparatiboa predikatuari lotzen zaionean numero morfologia hautazko bihurtzen da:

(30) Ikasleak azkarrago(ak) dira hemen han baino

Numero zehaztapenik erakusten ez duten predikatuak ere -h.d. adjektiboa numero markarik 
gabe agertzen den kasuetan ere-, ezin daitezke komunztatzen ez diren zenbatzaileekin konbinatu, (31b)k erakusten duen bezala:

(31) a. Ikasle asko gu baino azkarrago/altuago dira b. * Ikasle asko gu baino azkarrago/altuago da

Badirudi beraz, arazoa ez dela numero markaren presentziaren ondorio, baizik eta predikatu motaren araberakoa.

(31a) eta (31b)ko adibideen arteko kontrastearen beste azalpen posible bat ere baztertu nahiko genuke. Ikuspegi batzuen arabera, EM eta IM predikatuak egitura informatiboaren aldetik ere bereizten dira (cf Raposo \& Uriagereka, 1995). Ideia honi jarraituz, Raposo \& Uriagerekak (1995) IM predikatuen subjektuak topiko bezala analizatu beharko liratekela argudiatzen dute. Japonieraz adibidez, IM predikatuen subjektuak - wa topiko markatzailearekin agertzen dira, EM predikatuen subjektuak ez bezala. Diferentzia honi helduaz, izan liteke zenbatzaile komunztaduragabeak topiko posizioan egoteko gai ez izatea? Entitate espezifikoei erreferentzia egiteko zailtasunak badituzte ere (ikus. 4.4 atala), zenbatzaile komunztaduragabeek ez dute arazorik topiko izateko, (32)k erakusten duen bezala.

(32) Ikasle asko BERANDU etorri da gaur

(32)n berandu adberbioak galdegai funtzioa betetzen du. Jakina da euskaraz galdegaiak aditzaren aurreko posizioa bete behar duela. Hau aditza-bigarren fenomeno bezala tratatu izan da (ikus Ortiz de Urbina, 1989). Analisi honetan, galdegaia perpausaren konplementatzaile eremuan dagoen posizio sintaktiko batera mugitzen da, eta aditza gehi laguntzailea erakartzen ditu atzetik. Mugimendu honek gaur denbora adberbioa aditzaren ondoko posizioan uzten du. Galdegaiaren analisi sintaktiko zuzena edozein dela ere (ikus Uriagereka, 1999; Elordieta, 2001; Arregi, 2003; Irurtzun, 2007; Etxepare and Uribe-Etxebarria, 2008), deskriptiboki argi geratzen dena da (32) adibideak foko sintaktikoa daukala. Fokoaren ezkerretara agertzen diren elementuak topiko bezala interpretatu ohi dira, eta (32)n, topiko posizioa zenbatzaile komunztaduragabeak betetzen du. (31b)ren ezgramatikaltasuna ez da beraz subjektua topiko izatearen ondorio.

\subsection{Enumerazioa eta anafora}

Komuntatzen diren zenbatzaileekin alderatuz, zenbatzaile komunztaduragabeek erakusten duten beste propietate bat da indibiduo zehatz eta espezifikoei ezin dietela erreferentziarik egin. Horrela, komunztaduragabeak, komunztaduradunak ez bezala, ezin daitezke anaforen aitzindari izan, (33b)n erakusten denez.

(33) a. Bezero asko ${ }_{i}$ sartu dira gaur. ${ }_{-i}$ ez dira oso pozik atera

b. * Bezero asko, sartu da gaur. ${ }_{-i}$ ez da oso pozik atera

(34) adibidean enumerazio kasuak erakusten ditugu: Zenbatzaile komunztaduradunek indibiduo zehatzen enumerazioa inolako arazorik gabe baimentzen dute, hau da, posible da hitzegiten ari garen multzoko kideei erreferentzia egitea, (34a). Aldiz, zenbatzaile komunztaduragabeekin konbinatzen den izenaren denotazioaren enumeraziorik ezin egin daiteke, (34b). 
(34) a. Jonek ikasle asko ikusi ditu: Jon, Mikel, Pello, Martxel...

b. * Jonek ikasle asko ikusi du: Jon, Mikel, Pello, Martxel...

\subsection{Zenbatzaile kardinalak}

Lehen sistema honen beste propietate bat da kardinalek, gainerako zenbatzaile ahulek ez bezala, komunztadura egin behar dutela. Esaldia gramatikala izango bada, kardinalek beti numero komunztadura erakustsi behar dute. Eta hau zeinnahi posiziotan:

(35) a. Hiru lagun etorri *da/dira

b. Jonek hiru ikasleri esan *dio/die festara etortzeko

c. Jonek hiru ikasle ikusi *du/ditu festan

\section{Trantsizio Sistema: "Lapurdikoa"}

\subsection{Komunztatzen ez diren zenbatzaileen distribuzio sintaktikoa}

Trantsiziosistemadeitudugun honekbadualderikzenbatzailekomunztaduragabeen distribuzioan Mendebale-Erdialdeko sistemarekin konparatuta. Han zenbatzaile komunztaduragabeak posizio sintaktiko guztietan ager badaitezke ere, honetan ez da horrela gertatzen: S posizioan agertu daitezke, baina bakarrik kasu absolutiboarekin (36a), kasu ergatiborik ez dute onartzen (36a); ZO posizioan agertu daitezke, kasu datiboarekin (36b), eta baita OZ posizioan ere, kasu absolutiboarekin (36c). Beraz, arazoa zenbatzaile komunztaduragabea kasu ergatiboarekin konbinatzean sortzen dela ematen du.

(36) a. Subjektua:

Kasu erg.: * Azkenean gazte anitzek altxatu behar izan zuen harria

Kasu abs.: $\quad$ Ikasle anitz jin da festara

b. Zehar objektua:

Kasu dat.: $\quad$ Ugazabak langile anitzi eskatu dio laguntza

c. Objektu zuzena:

Kasu abs.: $\quad$ Mirenek liburu anitz ikusi du liburutegian

\subsection{Komunztaduragabeen izaera distributiboa}

\subsubsection{Irakurketa kolektibo eta distributiboak}

Sistema honetan, komunztaduragabeak kasu ergatiboa erabiliz agertu ezin daitezkenez (ikus (36a)), zaila da jakiten beren izaera benetan distribuziozkoa den ala ez. Izan ere, zerbaitek irakurketa distributiboak bultzatzen dituen ala ez jakiteko modurik errezena S posizioan agertzen deneko adibideak baitira.

(37) Azkenean gazte anitzek altxatu behar izan zuten harria

$\checkmark$ kolektiboa $\quad \checkmark$ distributiboa

(38) * Azkenean gazte anitzek altxatu behar izan zuen harria

$$
\text { * kolektiboa * distributiboa }
$$

(37)ko adibidean, zenbatzaile ahul komunztaduradun batekin subjektu posizioan, bi irakurketa lortu ditzakegu, kolektiboa eta distributiboa (lehenengo sisteman gertatzen zen bezala). Kontua da, zenbatzaile komunztaduragabeak kasu ergatiborik ez onartzeak (38) bezalako esaldi bat 
zuzenean ezgramatikala egiten duela, eta ondorioz, irakurketa posibleak zein diren eta (37)rekin alderik badagoen ezin esan daitekela.

Hala ere, hurrengo bi azpiataletan erakusten dugu Trantsizioko sistema honetan zenbatzaile komunztaduragabeen propietateen artean distributiboak izatearena ere badagoela.

\subsubsection{Predikatu klaseak}

Zenbatzaile komunztaduragabeak distributiboak badira banakako interpretazioa onartzen ez duten predikatuekin ez dira ondo joango. Predikzioa, (39-41) adibideek garbi erakusten duten bezala, bete egiten da sistema honetan ere. Komunztaduradunek berriz, ez dute inolako arazorik predikatu klase honekin konbinatzeko.

(39) a. Lantegian, langile anitz bildu dira

b. ?* Lantegian, langile anitz bildu da

(40) a. Jonek liburu anitz sailkatu ditu

b. ?? Jonek liburu anitz sailkatu du

(41) a. Mikelek ikasle anitz ikusi ditu elkarrekin

b. * Mikelek ikasle anitz ikusi du elkarrekin

\subsubsection{Elkarkariak}

Elkarkarien adibideak ere gauza bera erakustera datoz, hau da, sistema honetan zenbatzaile komunztaduragabeek izaera distributiboa dutela. Lehenengo sisteman bezalaxe, komunztaduragabeak ezin ager daitezke elkarkariekin batera, (42b) adibideak erakusten duen bezala.

(42) a. Gazte anitz joaten dira elkarrekin (ostatu horretara)

b. * Gazte anitz joaten da elkarrekin (ostatu horretara)

Are gehiago, aurreko adibidetik elkarrekin-en ordez bakarrik erabiltzen baldin badugu, esaldia erabat gramatikal bihurtzen da, (43b), komunztaduragabeen izaera distributiboa agerian utziz. Komunztatzen diren zenbatzaile ahulek ez dute arazorik ez adibide batean ez bestean agertzeko, desberdintasuna bakarra izango da: (42a)n irakurketa kolektiboa bakarrik lortuko dute, (43a)n ostera, irakurketa distributiboa bakarrik.

(43) a. Gazte anitz joaten dira bakarrik (ostatu horretara)

b. Gazte anitz joaten da bakarrik (ostatu horretara)

\subsection{Predikatu kategoriko eta thetikoak}

Trantsizio sistemako zenbatzaile komunztaduragabeak Mendebalde-Erdialde sistemako zenbatzaile komunztaduragabeak bezala portatzen dira eta ezin ager daitezke predikatu kategorikoekin, (44b).

(44) a. Ikasle anitz handiak/azkarrak dira

b. * Ikasle anitz handia/argia da

Aldiz, eta berriro ere lehenengo sistemako portaera berdina erakutsiz, predikatu thetikoekin ez dute inolako arazorik agertzeko, (45b) eta (46)n ikus daitekeenez. 
(45) a. Ikasle anitz gaiso(rik) daude egunotan

b. Ikasle anitz gaiso(rik) dago egunotan

(46) Anitz ikasle bada eri denik egunotan

\subsection{Enumerazioa eta anafora}

Espero bezala, eta lehen sisteman gertatzen denaren pare, Trantsizio sisteman ere zenbatzaile komunztaduragabeek ezin diezaiekete indibiduo zehatz eta espezifikoei erreferentziarik egin. Ondorioz, komunztaduragabeak ezin daitezke anaforen aitzindari izan (47b)n erakusten denez, ez eta berekin konbinatzen den izenaren denotazioaren enumeraziorik egin, (48b)

(47) a. Bezero anitz sartu dira gaur. ${ }_{-i}$ ez dira oso pozik atera

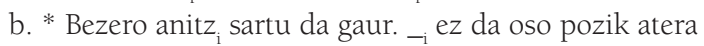

(48) a. Jonek ikasle anitz ikusi ditu: Jon, Mikel, Pello, Martxel...

b. * Jonek ikasle anitz ikusi du: Jon, Mikel, Pello, Martxel...

\subsection{Zenbatzaile kardinalak}

Berriro ere lehen sistemaren pare, zenbatzaile kardinalek ez dute komunztaduran alternantziarik erakusten sistema honetan ere: beti numero komunztadura erakusten dute beren posizio sintaktikoa edozein dela ere.

(49) a. Hiru lagun etorri *da/dira

b. Jonek hiru ikasleri esan *dio/die festara etortzeko

b. Jonek hiru ikasle ikusi *du/ditu festan

Beraz, Mendebalde-Erdialdeko sisteman eta Trantsiziokoaren arteko desberdintasun nagusia subjektu ergatiboaren ingurukoa da. Lehen sisteman komunztaduragabeek kasu ergatiboarekin konbinatzeko arazorik ez duten bitartean, Trantsizio sisteman hau ez da posible.

\section{Hirugarren sistema: "Zuberoakoa"}

\subsection{Komunztaduragabeen distribuzioa}

Zuberoakoa deitu dugun hirugarren sistema honen deskribapena egiteko Coyos-en (1999) Arbailako hizkeraren deskripzioan oinarritu gara. Sistema honetan ere, Trantsizio sisteman gertatzen zenaren antzera, zenbatzaile komunztaduragabeak ezin daitezke agertu posizio sintaktiko guztietan. S posizioan agertu daitezke, baina bakarrik kasu absolutiboarekin (51a), kasu ergatiborik ez du onartzen (50a). ZO posizioan ere ezin daitezke agertu, beraz, ez dute kasu datiboarekin agertzerik onartzen (52). Hona Coyos-en (1999: 232-234) aipamen bat: "N avec le datif et déterminé par un quantificateur indéfini: si l'indice de datif est present dans le syntagme verbal, ce sera celui avec le pluriel". Aldiz, OZ posizioan, kasu absolutioarekin, ez dute inolako arazorik agertzeko eta komunztatzea arrarotzat jotzen da, forma komunztaduragabea naturalena litzatekeelarik, (53). ${ }^{9}$

9. Perpausak guk asmatutakoak dira. Coyos-ek (1999) ez du kasu hauetarako bertako perpausik agertzen. 
(50) Subjektua:

Kasu erg.: $\quad$ a. * Auzo anitzek jan du

(51) Subjektua:

b. Auzo anitzek jan dute

Kasu abs.:

a. Auzo anitz jin da

b. Auzo anitz jin dira

(52) Zehar objektua:

Kasu dat.

a. Ugazabak langile anitzi eskatu die laguntza

b. * Ugazabak langile anitzi eskatu dio laguntza

(53) Objektu zuzena:

Kasu abs.: $\quad$ Mirenek arraultze anitz jan du

\subsection{Zenbatzaile kardinalak}

Aurreko bi sistemetan ez bezala, Zuberoako sistema honetan kardinalak komunztatu gabe erabil daitezke. Halere, beren distribuzio sintaktikoa oso murriztua da. Komunztadurarik erakusten ez duten kardinalak ezin erabil daitezke S posizioan. Subjektua kasu absolutibo edo ergatiboarekin azaltzeak ez du eraginik gramatikaltasunean, (54) eta (55) adibideek erakusten duten bezala.

(54) Absolutibo:

a. * Hiru ikasle jin da

b. Hiru ikasle jin dira

(55) Ergatibo:

a. * Hiru ikaslek egin du

b. Hiru ikaslek egin dute

ZO posizioan Coyos-en (1999: 232-234) aipamen bat dakarkigu berriro ere: " $\mathrm{N}$ avec le datif et déterminé par un numéral: si l'indice de datif est present dans le syntagme verbal, ce sera celui avec le pluriel". Hau da, [Num+Izena+dat] egiturak ditugunetan, komunztadura beharrezkoa da (56b) ren ezgramatikaltasunak erakusten duen bezala.

(56) a. Ugazabak hiru ikasleri eskatu die laguntza

b. * Ugazabak hiru ikasleri eskatu dio laguntza

OZ-ren posizioan azkenik, ez dago inolako arazorik zenbatzaile kardinala komunztatu gabe erabiltzeko, (57-59) adibideetan ikus daitekeenez.

(57) a. Bi urrats egin du

(Coyos 1999: 232-234)

b. Bi urrats egin ditu

(58) ... galduduc bi lekhu, bi guiçon galant

bay eta thonatu, hiruor legnu charmant... (Etchahun 1833: Desertuko Ihicic)

(59) ...hiruor andere aguertuco çaiola... (Cerquand 1875: Le Sabot de Barantol) ${ }^{10}$

10. Eskerrak Xarles Bidegain-i (58) eta (59) adibideen esistentziaz ohartarazteagatik. 


\section{Komunztaduragabeen portaera hiru sistemetan: laburbilduz.}

Laburbilduz, (60)ean duzue hiru sistemetan zenbatzaile ahulek eta zenbatzaile kardinal komunztaduragabeek erakusten duten portaera:

(60) Zenbatzaile ahulen eta kardinalen erabilera komunztaduragabea

\begin{tabular}{|lcc|cc|cc|}
\hline & 1.sistema: & mend.erd & 2.sistema: & "lapurdi" & 3.sistema: & "zuberoa" \\
\cline { 2 - 6 } & zenbatz. & kardinal & zenbatz. & kardinal & Zenbatz. & kardinal \\
\hline S erg. & BAI & EZ & EZ & EZ & EZ & EZ \\
\hline S abs. & BAI & EZ & BAI & EZ & BAI & EZ \\
\hline ZO & BAI & EZ & BAI & EZ & EZ & EZ \\
\hline OZ & BAI & EZ & BAI & EZ & BAI & BAI \\
\hline
\end{tabular}

\section{Artikuluaren erabilera (eza)}

\subsection{Zubereraz}

Komunztatzen ez diren zenbatzaile kardinalek erakusten duten distribuzioa zubererako izen biluziek agertzen dutena dakarkigu burura. Zubereraz posible da izen biluziak, hau da, izena bakarrik, artikulu, zenbatzaile ahul edo zenbatzaile kardinalik gabe, OZ posizioan erabiltzea. ${ }^{11}$

(61) a. Bortüan ikusi dut behi, ardi eta mando

b. Dembora da (...) içan deçadan diru

c. Sagar ebatsi dü
(Coyos 1999: 232)

(Bourciez 1895) ${ }^{12}$

(Manterola 2006)

Izen biluzi hauek interpretazio esistentziala (Carlson 1977) deitua lortzen dute. Interpretazio esistentziala diogunean esan nahi dugu (61)ko adibideetan ez garela behi, ardi, edo mando jakin (espezifiko) batzuen gainean hizketan ari, ez eta diru kantitate jakin baten gainean ere. Pentsatzekoa da irakurketa espezifikoa lortzeko, artikuluak pluraleko forman agertu beharko lukeela. Bestela esanda, ematen du zubererako izen biluziek pluraleko interpretazioa dutela. (61)ko adibideetan

11. Lan honetan ez dugu artikuluaren erabilera predikatu posizioan landuko (ikus Etxeberria prestakuntzan).

12. Gándara \& Santazilia 2007: (14)-tik hartutako adibidea. 
izenak denotatzen duen multzoak elementu bat baino gehiago izan behar du.

Erabilera hau ez da posible ez S (dela kasu ergatiboan, dela absolutiboan) ez ZO posizioan ere (62-63) adibideek argiro erakusten duten moduan.

(62) Subjektua:
a. Erg.: *Ikaslek egin du hori
Ikasleek egin dute hori
b. Abs.: *Ikasle jin da
Ikasleak jin dira

(63) Zehar objektua:
a. *Ikasleri eman diot liburu
b. Ikasleei eman diet liburu

\subsection{Beste hizkeretan}

Zubererako artikuluaren erabilera hau erabat aldentzen da beste hizkeretako artikuluaren erabileratik. Gainerako euskalkietan izen biluziak ezinezkoak dira eta artikuluaren presentzia ezinbestekoa da esaldia gramatikala izango bada (cf. Laka 1993, Artiagoitia 1997, 2002). ${ }^{13}$

(64) a. * Mendian ikusi ditut behi, ardi eta mando

b. Mendian ikusi ditut behiak, ardiak eta mandoak

(65) a. * Ricardok eta biok ardo edan dugu bazkaltzeko

b. Ricardok eta biok ardoa edan dugu bazkaltzeko

Hizkera hauetan, (hau da, Mendebalde-Erdialdeko eta Transizioko sistemetan), (64b) eta (65b)ko artikuludun objektuek bi interpretazio jaso ditzakete: (i) espezifikoa (multzo edo kantitate jakin, ezagun baten gainean ari garela; frantsesko les, espainoleko los edo ingeleseko the determinatzailearekin lortuko genukeena); (ii) esistentziala (multzo edo kantitate ez-jakin, ezezagun batetaz ari garela; ikus 8.3. atala)

\subsection{Hizkuntza erromantzeak}

Aipatu berri dugun zubererako izen biluzien distribuzioak eta artikuluaren erabilera ezak hizkuntza erromantzeen portaera dakarkigu gogora (batzuena behinik behin). Espainieraz adibidez, izen biluziak posible dira argumentu posizioan, baina OZ posizioan bakarrik gerta liteke hau (66a, b, c)k erakusten duten bezala (edo aditzaren ondorengo S posizioan, (66d)); ikus Bosque (1996) espainierako izen biluzien inguruan.

(66) a. Juan ha comido patatas

b. Pedro ha visto leones

c. Mikel ha bebido café

13. Ikus besteak beste, Artiagoitia (2002) edo Etxeberria (2005, 2007), non euskarako determinatzailearen bi analisi posible aurkezten diren. Lan hauetan ez dira (ez interes ezagatik, noski!!) zubererako datuak kontutan hartuak izan. 


\section{d. Llegaron estudiantes}

(66)ko izen biluziek, zubereran gertatzen den bezalaxe, interpretazio esistentziala deitua lor dezakete bakarrik.

$\mathrm{S}$ posizioan berriz, determinatzailearen presentzia beharrezkoa da esaldia gramatikala izango bada, (67). ${ }^{14}$

(67) a. *(Los) médicos trataron de salvar al niño que se moría

b. *(Los) estudiantes han comido patatas

c. *(Los) dinosaurios están extintos

d. *(Las) girafas son altas

\subsubsection{Numero marka: Espainiera vs. Zuberera}

Antzekotasunak antzekotasun, bada desberdintasun esanguratsu bat zubererako izen biluzien eta hizkuntza erromantzeetako izen biluzien artean, numero marka hain zuzen ere. Espainoleko izen biluziek $-\boldsymbol{s}$ plural markaren presentzia ezinbestekoa duten bitartean (68), zubererako izen biluziak benetako izen biluziak dira eta inolako markarik gabe agertzen zaizkigu (69).

(68) Espainoleko izen biluziak: patata-s, leone-s, estudiante-s...

(69) Zubererako izen biluziak: behi, ardi, mando...

Halere, ohar gaitezen, zubererako izen biluzien numero marka ezak ez du hauen pluraltasuna ezabatzen (ikus (61)) $)^{15}$ eta beren interpretazioa beti da plurala.

Gauzak horrela, sortzen zaigun galdera ondorengoa da: zubererako izen biluziek agerikoa ez den berezko plural marka ote dute? Euskaraz, ageriko numero marka $-\boldsymbol{k}$ da. $-\boldsymbol{k}$ pluralgilea artikuluaren presentziari hertsiki lotua dago (ikus Etxeberria 2005). Etxeberria eta Etxeparek berriz (2008, agertzekoa) proposatzen dute (Borer-i jarraiki, 2005), pluraltasuna bi mailatan markatua dela hizkuntza naturaletan: numero buru baten bitartez batetik (euskaraz $\boldsymbol{k} \boldsymbol{k}$ ) eta bestetik klasifikatzaile izaerako buru baten bitartez, izen biluzi zenbagarriak zenbaketa funtziorako pluralizatu egiten dituena. Erdialde eta mendebaldeko hizkeretan, hori zenbatzaile ahul baten laguntzarekin egin daiteke bakarrik. Zubereraz berriz, iduri luke berez ager daitekeela izen soilari lagunduaz. Klasifikatzaile honek ez luke aztarna fonologikorik utziko, baina izen zenbagarri biluzien pluraltasunaren eragilea izango litzateke. Zubererak izen biluziak baimentzen dituen kontestu beretan ager daitezke zenbatzaile kardinalak komunztadurarik gabe. Bi fenomenoen arteko lotura zehatza zein den ikerkizun uzten dugu momentuz (ikus Etxeberria eta Etxepare, prestatzen).

\section{Ondorioak}

Euskarazko zenbatzaile ahulek pluraleko komunztadurarik gabe agertzeko aukera dute. Artikulu honek fenomeno horren baitan gertatzen den bariazio dialektala aztertu du. Azterketa honek

14. Ikus Bosque (1996: 73 orr.).

15. Chierchia (1998) jarraituz, masen izaera pluraltasunarekin lotua dagoela onartzen dugu. 
gutxienez hiru sistema bereizi behar ditugula erakusten du: mendebalde-erdialdekoa deitu duguna, trantsiziokoa (Lapurdiko hiztun zenbaitetan aurkitu duguna) eta ekialdekoa deitu duguna, Coyosen (1999) arbailetako hizkeraren azterketan oinarrituz agertu duguna. Diferentziak bi mailatakoak dira: batetik, komunztadura eza zein kontestu sintaktikotan gertatzen den. Erdialdeko-mendebaldeko hizkerek argumentu guzietan agertzen dute; trantsiziokoak ez du ergatiboarekin agertzen, eta ekialdeko hizkerek absolutiboekin bakarrik onartzen du. Bestetik, fenomenoa erakusten duten zenbatzaileen multzoa bera da bariazio eragile: zubereraz, zenbatzaile kardinalek ez dute zertan pluraleko komunztadura egin; beste sistemetan komunztadura ezinbestekoa da. Diferentzia hau beste batekin lotzen da iduriz: bakarrik zubereraz dira posible izen biluziak. Izen biluzi hauek zenbatzaile kardinal komunztaduragabeek agertzen duten distribuzioa ia berdina erakusten dute.

\section{Erreferentziak}

Artiagoitia, X. 2002. 'The functional structure of Basque noun phrases'. In X. Artiagoitia et al. (eds), Erramu Boneta: Festschrift for Rudolf P. G. de Rijk. Vitoria-Gasteiz: ASJU (EHU-UPV). 73-90.

Aurrekoetxea, G. \& X. Bidegain. 2004. Haur prodigioaren parabola Ipar Euskal Herriko 150 bertsiotan. Bilbo: ASJUren gehigarriak, XLIX.

Bosque, I. 1996. 'Por qué determinados sustantivos no son sustantivos determinados. Repaso y balance'. In I. Bosque (ed), El Sustantivo sin Determinación. Madrid: Visor. 13-119.

Carlson, G. 1977. Reference to kinds in English. Doktorego tesia, Umass.

Chierchia, G. 1998. 'Plurality of mass nouns and the notion of "semantic parameter"'. In S. Rothstein (ed), Events and Grammar. Dordrecht: Kluwer. 53-103.

Coyos, B. 1999. Le parler basque souletin des Arbailles: Une approche de l'ergativité. Paris: L'Harmattan.

Etxeberria, U. 2005. Quantification and domain restriction in Basque. Doktorego tesia, UPV-EHU $\leftleftarrows$ HiTT.

—. 2007. 'Definites can be existentially interpreted'. Proceedings of CLS 43. Chicago.

—. 2008. 'On quantification in Basque and on how some languages restrict their quantificational domain overtly'. In L. Matthewson (ed.), Quantification: A crosslinguistic perspective. London: Emerald

Etxeberria, U. \& R. Etxepare. 2008. 'Izen eta Gertakarien Gaineko Kuantifikazioa'. In X. Artiagoitia et al. (eds.), Gramatika Jaietan. Patxi Goenagaren Omenezko Liburua. Vitoria-Gasteiz: ASJU.

Etxeberria, U. \& R. Etxepare. agertzekoa. 'When Quantifiers won't agree'. In Blanca Urgell et alia (eds.), Mitxelena Katedraren Agiriak. EHU.

Etxepare, R. 2000. 'Asko-ren zenbait alderdi'. Lapurdum V.

Euskaltzaindia. 1985. Euskal Gramatika Lehen Urratsak I. Iruñea.

Gándara, A. \& E. Santazilia. 2007. Zehaztapen batzuk artikuluaren erabileraz Bourciez korpusean. Eskuizkribua. UPV-EHU

Heim, I., H. Lasnik eta R. May. 1991. 'Reciprocity and plurality'. Linguistic Inquiry 22:1: 63-101.

Koslicki, K. 1999. 'The semantics of mass predicates'. Noûs 33:1, 46-91.

Kuroda, Y. 1972. 'The categorical and the thetic judgement'. Foundations of Language 9, $153-$ 185. 
Manterola, J. 2006. '-a euskal artikulu definituaren gainean zenbait ohar'. In J. Lakarra \& J. I. Hualde (ed.), Studies in Basque and Historical Linguistics in Memory of R.L. Trask - R.L. Trasken oroitzapenetan ikerketak euskalaritzaz eta hizkuntzalaritza historikoaz. Donostia-Bilbo: Gipuzkoako Foru Aldundia-EHU. ASJUren gehigarriak. 651-676.

Milsark, G. 1977. Existential sentences in English. Doktoradutza tesia. MIT.

Ortiz de Urbina, J. 1989. Parameters in the grammar of Basque. Foris, Dordrecht.

Pelletier, J. \& L. Schubert. 1989. 'Mass expressions'. In D. Gabbay \& F. Guenthner (eds.), Handbook of Philosophical Logic, IV, 327-407.

Rotaetxe, K. 1979. 'Numeral eta aditzen arteko konkordantziaz'. FLV 32, 259-267.

Txillardegi. 1977. Oinarri bila. Donostia.

—. 1978. Euskal gramatika. Ediciones Vascas: Donostia.

Zabala, I. 2003. 'Nominal predication: copulative sentences and secondary predication'. In J. I. Hualde \& J. Ortiz de Urbina (eds.), A Grammar of Basque. Berlin: Mouton de Gruyter. 